\title{
STUDY OF THE 16 EU-JECFA PAHS INTERACTION WITH THE ARYL HYDROCARBON RECEPTOR (AhR) USING RAT AND HUMAN REPORTER CELL LINES
}

\author{
Catherine BRASSEUR ${ }^{1}$, Danielle MELENS ${ }^{1}$, Marc MULLER ${ }^{2}$, Guy MAGHUIN-ROGISTER ${ }^{1}$ and Marie- \\ Louise SCIPPO \\ ${ }^{1}$ University of Liège, Department of Food Sciences, Laboratory of Food Analysis, B43bis, Boulevard de Colonster 20, B- \\ 4000 Liege, Belgium \\ ${ }^{2}$ University of Liège, Molecular Biology and Genetic Engineering (CBIG/GIGA), B34, Avenue de l'hopital 1, B-4000 \\ Liege, Belgium
}

\section{Introduction}

Polycyclic aromatic hydrocarbons (PAHs) are toxic environmental and food contaminants which are formed during the incomplete burning of organic substances. They are widely dispersed in the environment due to domestic and industrial activities as wood, coal, oil, gas combustions or industrial garbage burning. Moreover, these compounds are formed by foodstuff transformation processes (i.e. cooking, drying or smoking processes) which can contribute to the main source of human contamination as well as cigarette smoking.

Polycyclic aromatic hydrocarbons are well-known as carcinogenic, mutagenic and genotoxic compounds ${ }^{1}$. Many studies have demonstrated the different toxicological pathways of the PAHs. One of them is the cellular aryl hydrocarbon receptor (AhR) activation which can be evaluated with the in vitro CALUX bioassay (Chemically Activated LUciferase gene eXpression). However, several studies have reported that the AhR activation is tissue and species dependant ${ }^{2}$.

In this study, we evaluated and compared the AhR-activation by the 16 priority PAHs of the list proposed by the European Union and the Joint FAO/WHO Expert Committee on Food Additives (EU-JECFA) ${ }^{3}$. We used four different recombinant reporter gene cell lines: two human hepatoma (HEPG2-Luc-ULg) and mammary carcinoma (T47D-Luc-ULg) cell lines and two rat hepatoma cell lines (H4IIE-Luc-BDS, H4IIE-Luc-ULg), which differ either by the tissue or the species they originate from, either by the promoter of the reporter gene expression vector.

As benzo(a)pyrene $(\mathrm{BaP})$ is the PAH reference compound, the BaP relative response potency (REP) of each compound was evaluated and these REP values were compared with the Toxic Equivalent Factor (TEF) values already established for several PAHs.

\section{Materials and methods}

Individual standard solutions of the 16 EU-JECFA PAHs list were purchased from Cluzeau Info Labo (Putteaux la Défense, France). 2,3,7-8 Tetrachlorodibenzo-p-dioxin (TCDD) was purchased from Wellington laboratories (Canada).

The rat hepatoma H4IIE-Luc-BDS cell line was obtained from BioDetection System (DR-CALUX ${ }^{\circledR}$, Amsterdam, The Netherlands). This recombinant cell line is stably transfected with the pGudLuc 1.1 expression vector, containing the firefly luciferase gene under transcriptional control of four DREs from the 5'-flanking region of the mouse CYP1A $1^{2}$.

The rat hepatoma H4IIE-Luc-ULg, the human hepatoma HepG2-Luc-ULg and the human mammary tumoral T47D-Luc-ULg are "home-made" recombinant cell lines. The cell lines were obtained from the American Type Culture Collection (ATCC, Manassas, VA) and were transformed in the Molecular Biology and Genetic Engineering Laboratory of Liège (Belgium). For the CALUX test, the cells were seeded on 96-well cell culture plates and, after $24 \mathrm{~h}$ of growth, exposed during $6 \mathrm{~h}$ or $24 \mathrm{~h}$ to PAHs standard solutions dissolved in medium. Lysis solution (Triton X-100) and then luciferase substrate (luciferin) were added in each well. The produced light was measured with a luminometer (ORION II, Berthold Detection System, Pforzheim, Germany), in a dose responsive way. 


\section{Results and discussion}

\section{Influence of the exposure time}

AhR-activating compounds such as TCDD are most of the time stable compounds so that the CALUX test is usually achieved with an optimal exposure time of $24 \mathrm{~h}$. As polycyclic aromatic hydrocarbons are cells metabolized compounds, different exposure times lower than $24 \mathrm{~h}$ were tested with the PAH reference compound benzo(a)pyrene $(\mathrm{BaP})$ in order to obtain greater CALUX responses. The EC50 values calculated with the doseresponse curves obtained from different exposure time for TCDD and BaP are compared on fig.1. The results show that $24 \mathrm{~h}$ is not the optimal exposure time for BaP. The exposure time of $6 \mathrm{~h}$ was chosen as the minimal stable time to obtain greater CALUX responses for PAHs and was tested with all the compounds. For the compounds benzo(c)fluorene, cyclopenta(cd)pyrene, benzo(ghi)perylene and dibenzo(a,l)pyrene which did not induce CALUX responses after an exposure time of $24 \mathrm{~h}$, low responses were obtained after exposing the cells during $6 \mathrm{~h}$, but these compounds were unable to generate a dose-response curve (results not shown).
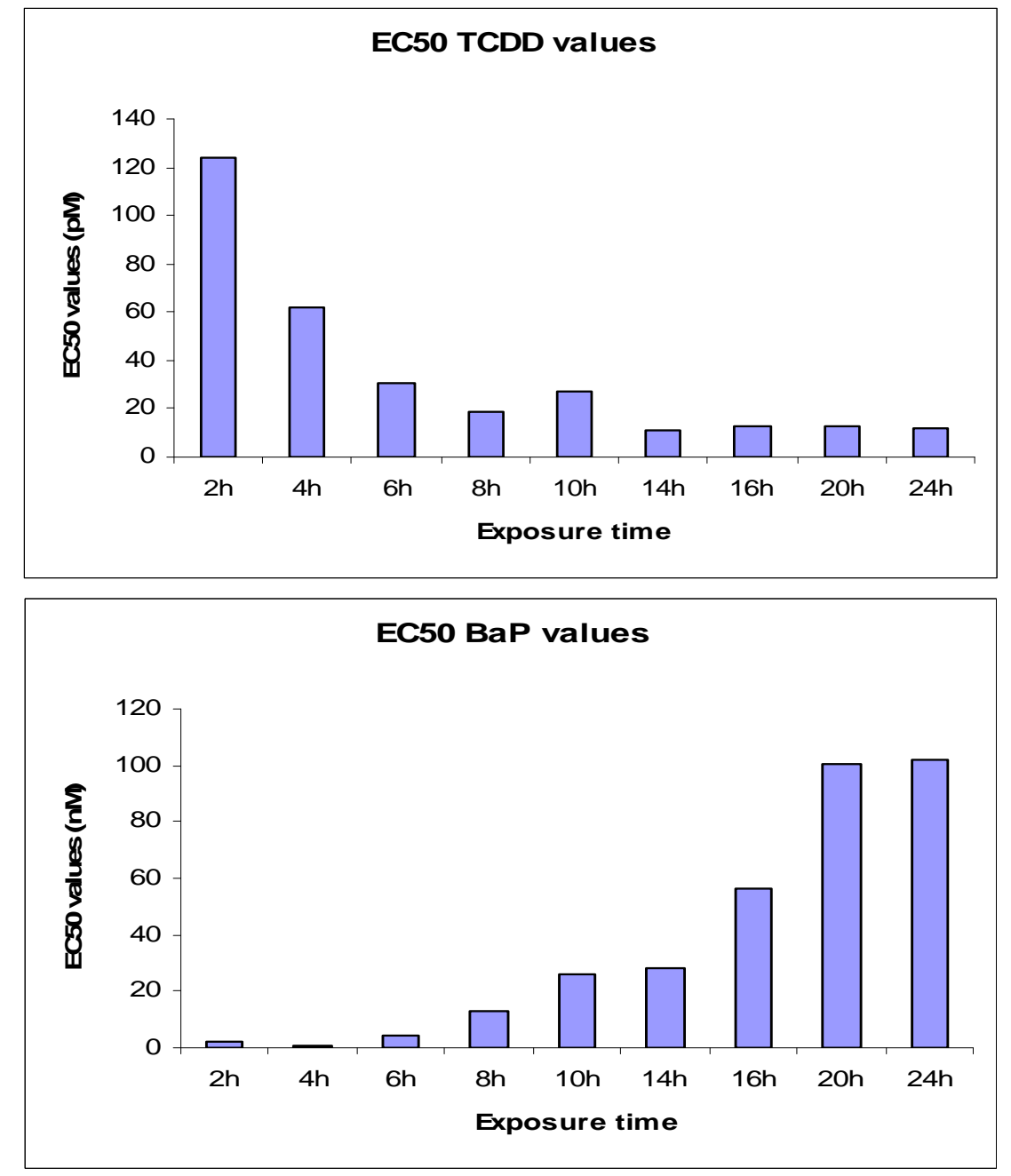

Figure 1: Influence of the exposure time on the EC50 values obtained with TCDD and BaP when achieving the CALUX bioassay (the results were obtained with the H4IIE-Luc-BDS recombinant cell line). 


\section{Influence of the recombinant cell line specificity on the CALUX results}

Several studies have already reported the species- and tissue-specific differences of the AhR-activation. According to that, the influence of the recombinant cell line specificities on CALUX results must be considered. The first step was to evaluate the responsiveness of the four different recombinant cell lines of this study, especially for the BaP reference compound. The dose-response curves obtained with the different cell lines, after $6 \mathrm{~h}$ of exposure to the cells are shown on fig.2. The rat hepatoma H4IIE-Luc-BDS recombinant cell line showed the greatest responsiveness as the most important CALUX response was obtained with these cells for the different $\mathrm{BaP}$ levels tested. In comparison, the response obtained with the rat hepatoma H4IIE-Luc-ULg cell line was lower than that obtained with the H4IIE-Luc-BDS. These two cell lines differ by the reporter vector used for the transformation. The two human hepatoma and tummoral mammary recombinant cell lines showed similar $\mathrm{BaP}$ dose-response curves but the concentrations needed were 3 to 40 fold higher than those used with the rat cell lines.

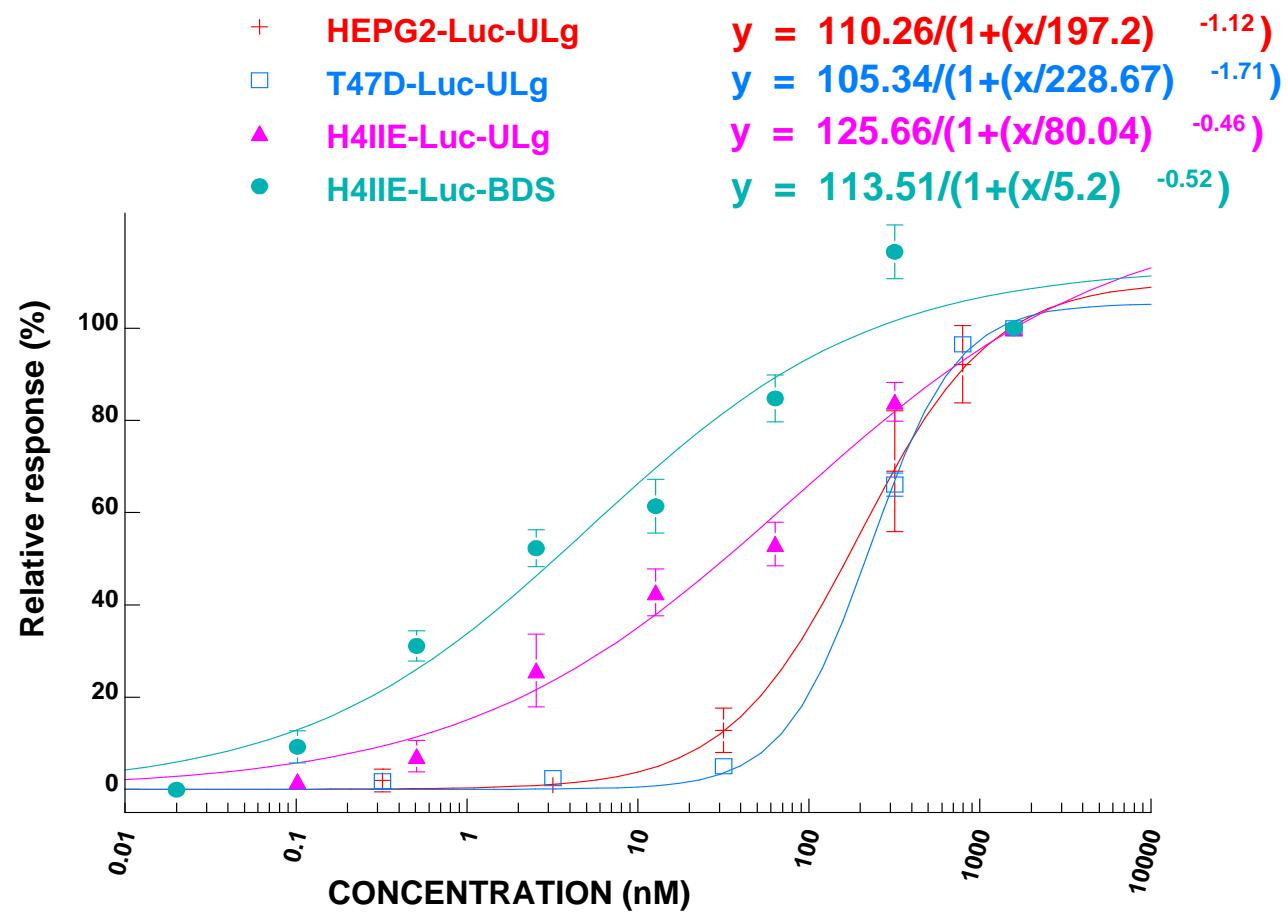

Figure 2: Comparison of BaP dose-response curves obtained with the CALUX test with the four recombinant cell lines and with $6 \mathrm{~h}$ of exposition. The curves are based on results obtained with minimum three independent experiences.

\section{Evaluation of BaP relative potencies (REPs) of the $16 \mathrm{UE}-J E C F A$ PAHs with the different CALUX tests}

$\mathrm{BaP}$ relative potencies of each PAH of the European list were evaluated with the different recombinant cell lines. The REP50 BaP calculated values, summarized in Table 1, are based on results obtained after $6 \mathrm{~h}$ of exposure. According to the H4IIE-BDS results, REP50 BaP values greater than 1 were obtained for the benzo(k)fluoranthene, the benzo(b)fluoranthene, the benzo(j)fluoranthene, the dibenzo(a,h)anthracene, the dibenzo(a,i)pyrene and the indeno(123-cd)pyrene (except for the benzo(j)fluoranthene with the T47D-ULg cell line), meaning they are more potent than the $\mathrm{BaP}$ regarding to the AhR activation property, in all the recombinant cell lines used. On the same way, no REP50 BaP values could be calculated for cyclopenta(cd)pyrene, benzo(ghi)perylene and dibenzo(a,l)pyrene because too weak responses were induced in all the cell lines. However, differences were observed with some PAH compounds, particularly when they were tested with the HepG2 cell line: chrysene, 5-methylchrysene and dibenzo(a,e)pyrene did not induce significant 
responses only with the HepG2-ULg cells as the REP50 BaP values obtained for these compounds with the others cell lines were quite similar. In opposition, the greatest REP50 BaP values were obtained for the benzo(k)fluoranthene, the dibenzo(a,h)pyrene, the indeno(123-cd)pyrene and the dibenzo(a,i)pyrene with the HepG2 cell line. In general, similar REP values were obtained with the H4IIE-BDS, the H4IIE-ULg and the T47D-ULg as the HepG2-ULg cell line showed various results.

When comparing the evaluated REP50 BaP values with some established INERIS TEF values ${ }^{4}$, the results showed that most of the REP50 BaP values are higher than the proposed INERIS TEF values. Furthermore, according to the REP BaP values of this study, most of the PAHs have greater response potency than the BaP reference compound, which is not the case for the PAHs TEF values.

REP50 BaP (6h)

\begin{tabular}{lcccccc}
\hline PAHs & MW & TEF $_{\text {INERIS }}$ & H4IIE-BDS & H4IIE-ULg & HepG2-ULg & T47D-ULg \\
Benzo(c)fluorene & 216 & - & 0.0005 & $\mathrm{NC}$ & $\mathrm{NC}$ & 0.4 \\
Cyclopenta(cd)pyrene & 226 & 0.1 & $\mathrm{NC}$ & $\mathrm{NC}$ & $\mathrm{NC}$ & $\mathrm{NC}$ \\
Benzo(a)anthracene & 228 & 0.1 & 0.4 & 1 & 0.4 & 0.8 \\
Chrysene & 228 & 0.01 & 0.5 & 0.5 & $\mathrm{NC}$ & 0.4 \\
5-methylchrysene & 242 & - & 0.4 & 4 & $\mathrm{NC}$ & 0.3 \\
Benzo(b)fluoranthene & 252 & 0.1 & 10 & 6 & 3 & 1 \\
Benzo(k)fluoranthene & 252 & 0.1 & 5 & 6 & 152 & 11 \\
Benzo(a)pyrene & $\mathbf{2 5 2}$ & $\mathbf{1}$ & $\mathbf{1}$ & $\mathbf{1}$ & $\mathbf{1}$ & $\mathbf{1}$ \\
Benzo(j)fluoranthene & 252 & - & 5 & 8 & 3 & 0.8 \\
Indeno(123-cd)pyrene & 276 & 0.1 & 2 & 5 & 23 & 2 \\
Benzo(ghi)perylene & 276 & 0.01 & $\mathrm{NC}$ & $\mathrm{NC}$ & $\mathrm{NC}$ & $\mathrm{NC}$ \\
Dibenzo(a,h)anthracene & 278 & 1 & 4 & 11 & 63 & 16 \\
Dibenzo(a,e)pyrene & 302 & - & 0.3 & 0.8 & $\mathrm{NC}$ & 0.3 \\
Dibenzo(a,h)pyrene & 302 & - & 0.5 & 7 & 0.7 & 2 \\
Dibenzo(a,i)pyrene & 302 & - & 1 & 6 & 68 & 5 \\
Dibenzo(a,l)pyrene & 302 & - & $\mathrm{NC}$ & $\mathrm{NC}$ & $\mathrm{NC}$ & $\mathrm{NC}$
\end{tabular}

Table 1: Comparison of the REP50 BaP values of the 16 EU-JECFA PAHs and INERIS TEF values. The REP values were evaluated with the CALUX test using different recombinant cell lines.

NC : REP could not be calculated, dose-response relationship insufficient for estimate

REP values were evaluated with dose-response curves based on results obtained with minimum three independent experiences.

\section{References}

1. Opinion of the Scientific Committee on Food on the risks to human health of Polycyclic Aromatic Hydrocarbons in food, 4 December 2002, SCF/CS/CNTM/PAF/29/Final

2. Garrison P.M., Tullis K., Aarts J.M.M.J.G., Brouwer A., Giesy J.P., Denison M.S. Fundam. Appl. Toxicol., 1996, 30, 194-203.

3. Evaluation of certain food additives (Sixty-fifth report of the Joint FAO/WHO Expert Committee on Food $\begin{array}{llllll}\text { Additives). } & \text { WHO } & \text { Technical } & \text { Report } & \text { Series, } & \text { No. }\end{array}$ http://whqlibdoc.who.int/trs/WHO_TRS_934_eng.pdf

4. Institut National de l'environnement industriel et des risques (INERIS).

Hydrocarbures Aromatiques Polycycliques (HAPs) Evaluation de la relation dose-réponse pour des effets cancérigènes : Approche substance par substance (facteur d'équivalence toxique-FET) et approche par mélanges. Rapport final, 18 décembre 2003. [en ligne] (03/01/2006)

http://www.ineris.fr/index.php?module=doc\&action=getDoc\&id_doc_object=2269

This project is financed by the SPF (Service Public fédéral) Santé Publique, Sécurité de la Chaîne alimentaire et Environnement, "Recherche contractuelle", BELGIUM 